\title{
Characterization of Salmonella species from water bodies in Dar-Es-Salaam city, Tanzania
}

\section{Caracterização de espécies de Salmonella a partir de corpos hídricos em Dar-Es-Salaam, cidade, Tanzânia}

\author{
Beda J. Mwang'onde ${ }^{1,2}$, Donatha D. Tibuhwa ${ }^{1}$, Lucy A. Namkinga ${ }^{1}$, Eliningaya J. Kweka ${ }^{2 \dagger}$
}

1. University of Dar es Salaam, Department of Molecular Biology and Biotechnology P.O.Box 35179, Dar es salaam Tanzania, 2. Tropical Pesticides Research Institute, Division of livestock and Human disease vectors, P.O. Box 3024, Arusha, Tanzania

\begin{abstract}
Background: Water-borne diseases are the most common cause of illness and death among the poor population from developing countries. The majority of the people are inadequately aware that aquatic environment is a major source of salmonellosis. Dar es Salaam city is among the cities with most of its population live in squatter. Typhoid fever ranks second with $14.3 \%$ of all notifiable disease cases in the city. The city experience water scarcity which forces water wells and rivers to become the main sources of water for domestic use and livestock. This study therefore, characterized Salmonella strains from different water bodies of city as possible sources for enteric diseases endemicity. Methods: The Salmonella Chromogenic Agar (SC Agar) and Kligler Iron Agar (KIA) media were used for isolation and enumeration of the strains. The inoculated cultures were incubated at $37^{\circ} \mathrm{C}$ for 24 hours. Salmonella colonies were confirmed by magenta colorations and hydrogen sulfide production on SC Agar and KIA Agar, respectively. The Analytical Profile Index 20 Enterobacteriaceae kit (API 20E kit) was used to identify Salmonella species. Results: Based on the API 20E kit, the identified Salmonella species from different water bodies were Salmonella ser. paratyphi A (96.9\%), Salmonella cholelaesuis spp choleraesuis (99.5\%) and Salmonella typhi (99.9\%). Conclusion: This study shows that shallow wells and rivers which are mainly used by the city dwellers were highly contaminated with Salmonella and were more contaminated than deep wells and marine water bodies. This warrants further investigation on the disease mapping in the urban and peri-urban areas.
\end{abstract}

Keywords: Salmonella typhi. Salmonellosis. Water pollutants. Wells. River pollution.

\section{Resumo}

Introdução: Doenças transmitidas pela água são as causas mais comuns de doença e morte entre a população pobre de países em desenvolvimento. A maioria das pessoas está ciente de que água poluída é uma importante fonte de salmonelose. A cidade de Dar es Salaam tem a maior parte de sua população residindo em favelas, sendo a febre tifoide a doença em segundo lugar, com 14,3\% das notificações de doenças obrigatórias. A carência de água na cidade faz com que as pessoas tenham que armazená-la em poços e rios para uso doméstico e pecuária.

Este estudo, portanto, caracteriza diferentes cepas de Salmonella de fontes de água da cidade como possíveis fontes de doenças entéricas. Métodos: Foram utilizados para o isolamento das cepas os meios de cultura Agar Salmonella Chromogenic (Agar SC) e KLIGLER Agar Ferro (KIA). As culturas inoculadas foram incubadas a $370^{\circ} \mathrm{C}$ durante 24 horas. Colônias de Salmonella foram confirmadas por coloração magenta e produção de sulfureto de hidrogênio em SC Agar Agar e KIA, respectivamente. O Perfil Analítico Índice 20 Enterobacteriaceae kit (kit API 20E) foi utilizado para identificar espécies de Salmonella. Resultados: Com base no Kit API 20E, as espécies de Salmonella identificadas de diferentes corpos d'água foram Salmonella paratyphi A (96,9\%), Salmonella spp cholelaesuis choleraesuis $(99,5 \%)$ e Salmonella typhi $(99,9 \%)$. Conclusão: Este estudo mostra que os pequenos poços e rios, que são utilizados principalmente pelos moradores da cidade, estavam muito contaminados com Salmonella e foram mais contaminados do que poços profundos e corpos d'água marinhos.

Palavras-chave: Salmonella typhi, Salmonelose, Poluentes da água, Poços, Poluição de rios.

\section{Background}

Salmonella species are important microorganisms for public health that colonize living organisms and natural environments. They are pathogenic species of bacteria, often detected in sewage, freshwater, marine coastal water and groundwater ${ }^{1}$. They can survive for long periods in natural waters, and the persistence of specific and epidemic strains is of great concern for public health. Salmonellae are potentially zoonotic ${ }^{2}$; they colonize the intestinal tracts of humans and other animals including birds; and they are the causative agent of typhoidal and non typhoidal diseases ${ }^{3}$. Salmonella can be transmitted through milk, water, or solid food contaminated with feces of typhoid patients or

Correspondence: pat.kweka@gmail.com

Ethical issues: The study proposal was approved by the University of Dar es Salaam research ethics committee.

Competing interest: Authors declare that they have no competing interest.

Received 21 Oct 2012; Revised 6 Nov 2012; Accepted 21 Jan 2013. 
carriers $^{3}$. There are three recognized species of Salmonella: S. typhi, S. choleraesuis, and S. enteriditis. Salmonella typhi is responsible for typhoid fever; and $S$. typhimurium which is a serotype of $S$. enteriditis cause gastroenteritis ${ }^{4}$.

There have been increasing illnesses and deaths among poor people that are associated with Salmonella contamination of water bodies. In mainland Tanzania statistics show that; in 2012, mortality rate due to typhoid fever is $20 \%$ (CIA Fact book) of all notifiable disease cases. Salmonellosis, a condition caused by these bacteria, is still increasing in third world countries and the researches have focused on the detection of Salmonella spp. from clinical samples and food sources ${ }^{4}$. The scarcity of water has lead people and animals to share the water bodies which are the most important sources of salmonellosis for humans and animals. In Dar es Salaam city, Tanzania, statistics show that, typhoid ranks fourth with $8 \%$ of all morbidities ${ }^{5}$. It is estimated that $88 \%$ of salmonellosis burden is attributable to unsafe water supply, lack of cleanliness and hygiene, and is more common in children from developing countries ${ }^{6}$.

Even though Dar es Salaam city has an estimated population of 2200 people $/ \mathrm{Km}^{2}$, it is poorly planned and practices an onsite waste disposal7. The water supply and sanitation infrastructures are behind the vertically growing city population. The available water sources have been shared with livestock and crop irrigation.

Detection of Salmonella strains in clinical samples have been reported by Vaagland et al.., ${ }^{8}$, Graham et al., ${ }^{9}$; in food samples by Wierup and Häggblom, ${ }^{10}$; Woldemariam et al., ${ }^{11}$ and Mdegela et al. ${ }^{12}$. However, Salmonella spp. in water bodies, which is one of the main routes of infection, is not adequately reported in Tanzania and information on the diversity and occurrence of Salmonella strains in water bodies is very scarce. This study therefore, intended to detect and characterize Salmonella serotypes from rivers, ponds, wells and marine waters of Dar es Salaam City.

\section{Methods}

\section{Sample collection}

Water samples were collected from different water courses in Dar es Salaam city which is located between latitudes $06^{\circ} 36^{\prime}$ and $07^{\prime \prime}$ to the south of Equator and longitudes $39^{\circ}$ and 33' $33^{\prime \prime}$ to the east of Greenwich. It is bounded by the Indian Ocean on the east and by the Coast region on the other sides. It has a multicultural population of 3.04 million people as per year $2008^{13}$ with a growth rate of $1.8 \%^{14}$.

The sample size was obtain based on the estimated prevalence of the variables of interest with 0.1 sampling proportion assumed to have safe water with the least desired level of precision (Kothari, 2004). Ninety (90) surface water samples were collected from ten and four randomly selected rivers (Buza, Msewe, Tegeta, Kizinga, Kilungule, Maziwa, UDSM and Ubungo) and ponds (Ubungo maziwa, Pugu, Kisukulu and Kunduchi) and 13 ocean water samples from the beach of Indian Ocean). There were 62 underground water samples from seven shallow dug wells (Kijitonyama, Ilala, Kurasini, Kinyerezi, Mabibo, Mtongani and Mbagala) and three deep drilled wells from (Sinza, Kisukulu and Kurasini) within Dar es Salaam City.

With the exception of deep drilled and shallow dug wells where spot collection was performed, public use/ interest (children play grounds, swimming, fetching water for domestic and animal use, points for irrigation water, resting and along ferry market beach) was the target for rivers, beach and ponds. Sterile bottles of $500 \mathrm{~mL}$ were used and water samples were analyzed within 6 hours after sampling. During sample collection (in rivers, ponds and ocean), the collecting bottles were submerged to a depth of about $20 \mathrm{~cm}$, with the opening facing slightly upward while those from wells, spot collection from water taps was used. The samples were collected three times from each point of collection at an interval of two months for a period of six months i.e. from December 2010 through May 2011, a period which encompassed both dry and rainy season. The bottle was then capped/corked and wrapped with aluminum foil and then transported to the Molecular Biology and Biotechnology laboratory of the College of Natural and Applied Sciences, University of Dar es Salaam.

\section{Membrane filtration and lactose tests}

Samples from all water bodies were subjected to filter assembly by the use of $0.45 \mu \mathrm{m}$ and $47 \mathrm{~mm}$ membrane filter. About $250 \mathrm{~mL}$ from each sample was used per each single filtration process. The filters were then inoculated in Salmonella Chromogenic Agar (PRONADISA Micro \& Molecular Biology, Switzerland). The inoculated cultures were incubated at $37^{\circ} \mathrm{C}$ for 24 hours. S. typhi and S. paratyphi, lactose positive Salmonella, sucrose positive and non-motile serotypes (S. pullorum and gallinarum) were assured for the presentation of Magenta colonies. Those colonies which had pronounced violet/purple/red magenta were subjected to Kligler Iron Agar (KIA) for the hydrogen sulfide production test.

\section{Kligler Iron Agar}

Kligler Iron agar (Acumedia manufacturers, Inc. USA) was used to sub-culture violet/purple/red magenta colonies from Salmonella Chromogenic Agar for $\mathrm{H}_{2} \mathrm{~S}$ production test. With the wire loop, characteristic colonies were picked and stabbed through the center of the agar to the bottom of the tube. Then, the sample was streaked in the surface of the slant of the Kligler Iron Agar. The tubes were incubated at $37^{\circ} \mathrm{C}$ for $18-24$ hours. Isolates which produced hydrogen sulfide with a characteristic black butt or ring with/out gas bubbles and an alkaline slant were considered Salmonella positive and were again grown onto Salmonella Agar 
for enumeration and obtaining pure colonies before subjecting the isolates to Analytical Profile Index 20 Enterobactereaceae test kit.

\section{Analytical Profile Index 20E test (API-20E)}

Bacterial suspensions from young ( 24 hours) pure colonies grown on Salmonella Chromogenic Agar were inoculated in API-20E kit. A suspension was made from several identical colonies, until reaching a turbidity equivalent to $0.5 \mathrm{McF}$ arland in the ampule of API 20 E Medium. The bacterial suspensions were inoculated to each cupule of the strip and then were incubated at $37^{\circ} \mathrm{C}$ for $24 \mathrm{hrs}$ during which, bacterial metabolites reacted with different sugars and their presence was detected by the change in the medium colour. The results were interpreted with the identification software (apiwebR1.2.1) and the reactions were read according to the reading Table and the identification software.

\section{Statistical Analyses}

Data entry and validation was carried out using ms-excel 2007 version (Ms Corp., Redmond, WA, USA). One way Analysis of Variance (ANOVA) was used to test for the significant differences between the prevalence of Salmonella in different water-bodies. Paired sample t-test was used to compare the prevalence of the bacteria between natural and artificial water courses. While single t-test was used to test for the differences in bacterial contamination in individual water courses, descriptive analyses in the form of columns was used to map the prevalence of Salmonella from different water bodies. The significance level for all tests was $5 \%(\alpha=0.05)$.

\section{Results}

Based on colony counts from selective Salmonella Chromogenic Agar, which enables growth of Salmonella spp (20 colonies) characterized by violet/purple or red magenta colonies and Escherichiacoli (9colonies) which is characterized by blue green colonies. Samples from rivers and marine (natural water courses) were significantly more contaminated than samples from deep drilled and shallow dug water wells $(\mathrm{t}=10.5369 ; \mathrm{df}=11 ; \mathrm{p}=7.82 \mathrm{E}-13$ ), however, within wells, shallow wells were significantly more contaminated than deep wells $(\mathrm{t}=10.5369 ; \mathrm{df}=11 ; \mathrm{p}=7.82 \mathrm{E}-13)$. River water samples revealed more colony counts than marine samples $(\mathrm{t}=13.544 ; \mathrm{df}=11 ; \mathrm{p}=1.82 \mathrm{E}-05)$, shallow well $(\mathrm{t}=13.544 ; \mathrm{df}=28 ; \mathrm{p}=2.56 \mathrm{E}-14)$ as well as deep wells $(\mathrm{t}=13.544 ; \mathrm{df}=28 ; \mathrm{p}=2.56 \mathrm{E}-14)$. While samples from shallow wells were more contaminated than those from marine sources $(t=7.169 ; \mathrm{df}=11 ; \mathrm{p}=1.82 \mathrm{E}-05)$, again marine samples were significantly more contaminated than samples from deep wells $(t=7.169 ; \mathrm{df}=11 ; \mathrm{p}=1.82 \mathrm{E}-05)$.

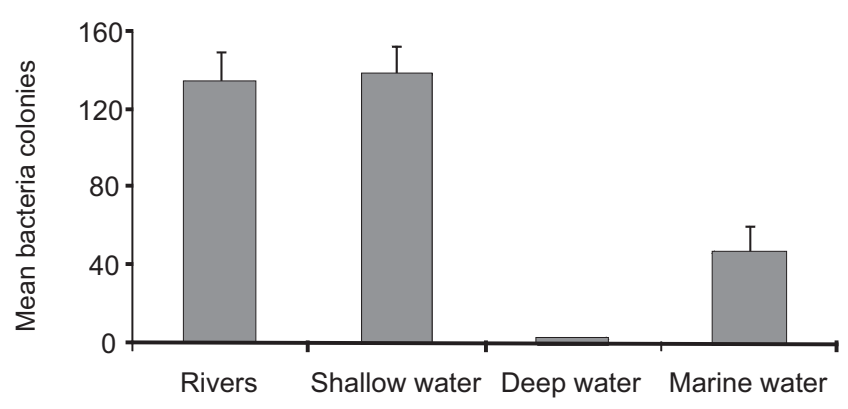

Figure 1 Mean number of bacteria colonies count from rivers, shallow wells, deep wells and marine water samples

A total of 165 samples from different water bodies were tested in which 49 of those tested positive to Salmonella in SC Agar. About 65\% $(n=49)$ of samples which shown Salmonella characteristic features in Salmonella Chromogenic Agar (SC Agar) were also detected Salmonella in Kligler Iron Agar. The SC Agar can differentiate Salmonella from Shigella and lactose-fermenting organisms. However, the problem has always been that colonies of non-lactosefermenting organisms that are not pathogenic can appear similar in appearance to Salmonella and must be subjected to further testing by using Triple Sugar Iron (TSI) Agar, Lysine Iron Agar (LIA), or Kligler Iron Agar (KIA).

In KIA, Salmonella spp showed a characteristic black butt and or ring with alkaline (red) slant and some samples were displaced by gas or had gas bubbles. The test vials showed gas formation which has replaced the media after 18 hours of incubation in $37^{\circ} \mathrm{C}$. Based on the Analytical Profile Index (apiwebR1.2.1) 20 Enterobateriaceae Kit test, there were three identified species of Salmonella which are Salmonella ser. Paratyphi A (96.9\%), Salmonella cholelaesuis choleraesuis (99.5\%) and Salmonella typhi (99.9\%), as per manufacturers manual. With API 20E Kit, bacterial identification is simple, rapid and reliable with $88 \%$ efficiency, $100 \%$ sensitivity and $96 \%$ specificity (BioMerieux, inc., Hazelwood, MO, France).

\section{Discussion}

Based on bio-chemical characteristics, Salmonella spp. loads were very high in rivers (natural water course) followed by shallow wells (artificial water source) of which are the commonest water sources for Dar-es-Salaam communities. However, species identification via apiwebR1.2.1 for the isolates from these different water bodies revealed three Salmonella strains i.e. Salmonella ser. Paratyphi A, S. choleraesuis spp choleraesuis and $S$. typhi. This signifies that bacteria of the genus Salmonella colonize a wide range of natural and constructed water bodies in Dar es Salaam City. The Dar es Salaam city is in lowland with high water table and poorly waste disposal system, contamination of shallow wells and rivers by human and animal wastes is inevitable. For marine, the interaction between domesticated and wildlife Salmonella host animals and the coastal watershed, 
the natural reservoirs in marine habitats, and the survival, prevalence and proliferation of the pathogens are a rational area of concern for disease emergence ${ }^{15}$. Constant release of Salmonella ser. paratyphi A; S. choleraesuis ssp choleraesuis; and S. typhi into water bodies is attributed by humans, pets, farm animals and wildlife ${ }^{16}$. Nevertheless, Stewart et al., ${ }^{15}$ stipulated that municipal sewage and storm water runoff are the conduits for the passage of disease pathogens into surface waters. In regards to discharge into the rivers representing a permanent source of pollution, flood events may mobilize a wide variety of Salmonella reservoirs located within the watershed and contribute to the dissemination of a large diversity of species which are transmitted to surface waters.

Despite high contamination in most of the river creeks in the city, this water remains the main source for crop production, livestock farming and playgrounds for children and fishing in some areas because piped water supply system is unreliable and not available to most households in the city. This dependence of water from contaminated sources jeopardizes human health.

Both serotypes isolated from this study are commonly isolated in human salmonellosis and can originate from healthy carriers ${ }^{17}$. Results of this study (Serotype Typhi and Paratyphi) being dominant in river samples and shallow wells also agree with the findings of Moriñigo et al., ${ }^{18,}$ ${ }^{19}$ and Nastasi and Mammina, ${ }^{20}$ who also reported high occurrence of these serotypes in polluted freshwaters in Spain and the United Kingdom, respectively. However, Haley et $a l_{.}{ }^{21}$ reported the presence of waterborne salmonellae in rural watersheds of Georgia (United States). Serotype Typhi is the dominant serotype commonly isolated from food and animal reservoirs but preferentially from human ${ }^{17}$. The presence of these culturable species in rivers and artificial shallow wells alone doesn't mean that they are not available in marine environment and perhaps deep wells. Evidences of contamination by livestock wastes in rivers are revealed by the presence of S.choleraesuis ssp choleraesuis, a serotypes of typhimurium in river samples.

Similarly, serotype Paratyphi $A$ which was found in rivers and shallow wells may be due to permanent onsite waste disposals by most of the city households. Deep wells were little contaminated with Salmonella; which might have been attributed to a number of reasons, such as local geological settings, land use and anthropogenic activities. Microbial movement in ground water can be controlled by physicochemical characteristics of the microbe, i.e. the microbe size, inactivation (die-off) rate, and surface electrostatic properties. According to Robertsona and Edbergb, ${ }^{22}$ inactivation or die-off rate is usually the most important factor governing how far microbes can migrate in significant numbers in groundwater. Moreover, properties of the aquifer, such as flow velocity, aquifer grain (or pore) size, porosity, solid organic carbon content, temperature, $\mathrm{pH}$, and other chemical characteristics of water and mineral composition affect the rate of contamination of underground water. These facts possibly contribute to less contamination of water from deep wells when compared to that from shallow and surface waters. This fact was also observed by Mwambete and Manyanga, ${ }^{23}$ in a study that focused on microbial quality of drinking water in Dar es Salaam city.

Identification of Salmonella serotypes from water bodies in Dar es Salaam city is potential to public health. However, some discrepancies with respect to conventional methods against the technique used to identify Salmonella under this study may be observed. There are different principles of the reactions used in the API technique in which substrate variations exist, that also accounts for percentage differences. The technique is effective to only pure cultures of a single organism and in case Salmonella are identified, serological identification would better be performed to confirm the bacterial identification.

\section{Conclusion}

Dar es Salaam city water bodies are contaminated by Salmonella species which are agents for typhoidal and non-typhoidal fever. This is risky to public and livestock health thus calling for an intensive cross-sectional study to discriminate species within a single serotype to assess the genetic diversity and/or variability within a given serotype. Further investigations are needed using serological methods and molecular markers in order to quantify and ascertain different serotypes found in different water bodies and their genetic heterogeneity and link them with clinical isolates from patients and regular hospital visitors in order to assess how risk and burden is the water courses in Dar es Salaam city to public health.

It is recommended that, public health education and improvement in sanitation and hygiene will help to control the problem from its source. To eradicate enteric fevers due to contaminated environment, studies should focus on both water and food based sources and clinical isolates. The results will alarm decision makers in prioritizing basic sanitary and hygiene measures including purifying water supplies, improving water delivery and sewage control, supplying hand-washing facilities, latrines, boiling water and supervising food-handlers as well as vetting on public awareness on source of diseases which may positively help and pave way towards better control strategies and for combating water sourced salmonellosis.

\section{Acknowledgements}

The authors are indebted to MBB department for granting a permit to conduct research in their laboratory, and the support of laboratory technicians in particular, Mr. Kimati and the Chief Laboratory Technician. 


\section{References}

1. Baudart J, Lemarchand K, Brisabois A, Lebaron P. Diversity of Salmonella strains isolated from the aquatic environment as determined by serotyping and amplification of the ribosomal DNA spacer regions. Appl Environ Microbiol. 2000 Apr;66(4):1544-52. doi: http://dx.doi. org/10.1128/AEM.66.4.1544-1552.2000. PubMed PMID: 10742240. PubMed Central: 92021.

2. Pan American Health Organization (US). Zoonoses and communicable diseases commone to man and animals. [Internet]. 3rd. Vol. 1, Bacterioses and Mycoses. Washington (D.C.): Pan American Health Organization (US); 2003. Salmonellosis; [cited 2012 Nov 10]; p. 23346. Available from: http://devserver.paho.org:8080/xmlui/bitstream/ handle/123456789/709/ZoonosesVol-1.pdf?sequence=1

3. Keddy KH, Dwarika S, Crowther P, Pyruvic O, Wadula J, Hoosen A, Sooka A, Crewe-Brown HH, Smith AM. Genotypic and demographic characterization of invasive isolates of Salmonella Typhimurium in HIV co-infected patients in South Africa. J Infect Dev Ctries. 2009;3(8):58592. doi: http://dx.doi.org/10.3855/jidc.549. PubMed PMID: 19801800.

4. Atherton F, Newman CP, Casemore DP. An outbreak of waterborne cryptosporidiosis associated with a public water supply in the UK. Epidemiol Infect. 1995 Aug;115(1): 123-31. doi: http://dx.doi. org/10.1017/S0950268800058180. PubMed PMID: 7641825. PubMed Central PMCID: 2271574.

5. Ministry of Health (TZ). Annual Health Statistical Abstract. Dar es Salaam: Ministry of Health; 2008.

6. World Health Organization $(\mathrm{CH})$, \& United Nations International Children's Emergency Fund (US). Progress on Drinking-water and Sanitation: Joint Monitoring Programme for Water Supply and Sanitation [Internet]. Geneva: World Health Organization; 2008 [cited 2009 Apr 12]. Available from: http://www.who.int/water_sanitation_ health.

7. City Mayors Foundation (UK). The largest cities in the world and their mayors. [Internet]. London (UK): City Mayors Foundation. 2006 - [cited 2012 Nov 10]. Available from: http://www.citymayors.com/statistics/ largest-cities-mayors-ad.html.

8. Vaagland $\mathrm{H}$, Blomberg $\mathrm{B}$, Krüger $\mathrm{C}$, Naman $\mathrm{N}$, Jureen $\mathrm{R}$, Langeland N. Nosocomial outbreak of neonatal Salmonella enterica serotype Enteritidis meningitis in a rural hospital in northern Tanzania. BMC Infect Dis. 2004 Sep 14;4:35. doi: http://dx.doi.org/10.1186/14712334-4-35. Pubmed PMID: 15367335. PubMed PMICID: 521073.

9. Graham SM, Molyneux EM, Walsh AL, Cheesbrough JS, Molyneux ME, Hart CA. Nontyphoidal Salmonella infections of children in tropical Africa. Pediatr Infect Dis J. 2000 Dec; 19(12):1189-96. Review. Pubmed PMID: 11144383

10. Wierup M, Haggblom P. An assessment of soybeans and other vegetable proteins as source of Salmonella contamination in pig production. Acta Vet Scand. 2010 Feb 17;52: 15. doi: http://dx.doi. org/10.1186/1751-0147-52-15. Pubmed PMID: 20158923.

11. Woldemariam E, Molla B, Alemayehu D, Muckle A. Prevalence and distribution of Salmonella in apparently healthy slaughtered sheep and goats in Debre Zeit, Ethiopia. Small Rumin Res. 2005 Apr;58(1):1924. doi: http://dx.doi.org/10.1016/j.smallrumres.2004.08.008.
12. Mdegela RH, Yongolo MGS, Minga UM, Olsen JE. Molecular epidemiology of Salmonella gallinarum in chickens in Tanzania. Avian Pathol. 2000 Oct;29(5):457-63. doi: http://dx.doi. org/10.1080/030794500750047216. Pubmed PMID: 19184838.

13. National Bureau of Statistics (TZ). Tanzania Population Projection 2003 to 2025 Report. Dar-es-salaam: Ministry of Planning, Economy \& Environment (TZ); 2008. p. 20-25.

14. World Bank Group (US). Annual report. [Internet]. Washington (D.C.): World Bank Group (US); 2007 - [cited 2012 Nov 10]. Available from: http://go.worldbank.org/E2OKMIRITO.

15. Stewart JR, Gast RJ, Fujioka RS, Solo-Gabriele HM, Meschke JS, Amaral-Zettler LA, et al. The coastal environment and human health: microbial indicators, pathogens, sentinels and reservoirs. Environ Health. 2008 Nov 7; 7 Suppl 2:S3. doi: http://dx.doi. org/10.1186/1476-069X-7-S2-S3. Pubmed PMID: 19025674. PubMed Central PMCID:2586716.

16. Geldreich EE. Water pollution: microbiology of water. J Water Pollut Control Fed. 1973 Jun; 45(6):1244-59. Pubmed PMID: 4355623.

17. Baudart J, Lemarchand K, Brisabois A, Lebaron P. Diversity of Salmonella Strains Isolated from the Aquatic Environment as determined by Serotyping and Amplification of the Ribosomal DNA Spacer Regions. Appl Environ Microbiol. 2000; 66(4):1544-52. doi: http://dx.doi.org/10.1128/AEM.66.4.1544-1552.2000. Pubmed PMID: 10742240. PubMed Central PMCID:92021.

18. Moriñigo MA, Cornax $R$, Castro $D$, Jimenez-Notaro $M$, Romero $P$, Borrego JJ. Antibiotic resistance of Salmonella strains isolated from natural polluted waters. J Appl Bacteriol. 1990 Mar; 68(3):297302. doi: http://dx.doi.org/10.1111/j.1365-2672.1990.tb02578.x. Pubmed PMID: 2341328

19. Moriñigo MA, Munoz MA, Martinez-Manzanares E, Sánchez JM, Borrego JJ. Laboratory study of several enrichment broths for the detection of Salmonella spp. particularly in relation to water samples. J Appl Bacteriol. 1993 Mar; 74(3):330-5. doi: http://dx.doi. org/10.1111/j.1365-2672.1993.tb03033.x. Pubmed PMID: 8468265.

20. Nastasi A, Mammina C. Epidemiological evaluation by PCR ribotyping of sporadic and outbreak-associated strains of Salmonella enterica serotype Typhimurium. Res Microbiol. 1995 Jan; 146(1): 99-106. doi: http://dx.doi.org/10.1016/0923-2508(96)80274-9. Pubmed PMID: 7754232.

21. Haley BJ, Cole DJ, Lipp EK. Distribution, diversity, and seasonality of waterborne salmonellae in a rural watershed. Appl Environ Microbiol. 2009 Mar; 75(5):1248-55. doi: http://dx.doi.org/10.1128/ AEM.01648-08. Pubmed PMID: 19124594

22. Robertsona J, Edbergb SC. Natural Protection of spring and well drinking water against surface microbial contamination. Crit Rev Microbiol. 1997;23(2):143 -78. Review. Pubmed PMID: 9226112.

23. Mwambete KD, Manyanga V. Microbial quality of drinking water in Dar es Salaam and use of Waterguard \#174 as disinfectant. Tanzania. Tanzania J Health Res. 2006 Jan; 21(1):22-4.

Como citar este artigo / How to cite this article:

Mwang'onde BJ, Tibuhwa DD, Namkinga LA, Kweka EJ. Characterization of Salmonella species from water bodies in Dar-Es-Salaam city, Tanzania. J Health Biol Sci. 2013 Jan-Mar;1(1):16-20. 